\title{
Social Pedagogy and Social Work: An analysis of their Relationship from a Socio-pedagogical Perspective
}

\author{
Ewa Marynowicz- \\ Hetka
}

\begin{abstract}
A proposal for the relationship between social pedagogy and social work will be made in this manuscript. It is assumed that social work is a certain type of practice cultivated by representatives of the social professions. Social pedagogy can provide an analysis of the field of social work, helping to orient activities within the field and to determine the proper selection of ways of conduct, a kind of a meta-theory. Such an approach enables interaction and cooperation between representatives of multiple disciplines within the humanities and social sciences who are engaged in social work. It also has consequences for the acceptance of multi-faceted and multi-dimensional approaches to activities in the field of social work, which is recognized as an important field for social pedagogues, allowing them to carry out social actions from various perspectives, socio-pedagogical among them. The socio-pedagogical perspective on social work will be analyzed in this article.
\end{abstract}

Keywords: social pedagogy, social work, field of practice, orientation of activity, relational model of social work, integrated paradigm

\section{Sociální pedagogika a sociální práce: Analýza vztahů ze sociálně-pedagogického hlediska}

\begin{abstract}
Abstrakt: $\mathrm{V}$ tomto príspěvku je analyzován návrh vztahů mezi sociální pedagogikou a sociální prací. Předpokládáme, že sociální práce je určitým druhem praxe kultivované představiteli sociálních profesí. Navíc může sociální pedagogika poskytnout určitou meta-teorii pro analýzu pole sociální práce, pro orientaci aktivit $v$ tomto poli a pro výběr způsobu chování. Takový př́stup nám umožňuje potkat představitele mnoha disciplín humanitních a společenských věd $v$ poli sociální práce a spolupracovat $s$ nimi. Převzetí takové pozice má za důsledek príijetí mnohotvaré a mnohadimenzionální prípravy aktivit $\mathrm{v}$ poli sociální práce. Uvědomujeme si, že sociální práce se může chápat jako jedno z důležitých polí aktivit sociálního pedagoga, ve kterém se sociální akce provádí z různých perspektiv. Jednou z nich může být sociálně-pedagogická perspektiva. Tento sociálně-pedagogický úhel pohledu je předmětem analýzy v tomto príspěvku.
\end{abstract}

Klíčová slova: sociální pedagogika, sociální práce, pole praxe, orientace aktivity, relační model sociální práce, integrované paradigma 


\section{The starting point: The imperative of modernity - searching for comprehensive knowledge for an analysis of the field in practice}

Contemporary social work is suspended between theory and practice, which are intertwined but nevertheless develop at different rates and in different contexts. For the development of social work in these two areas at the same time, as a practice and as an academic discipline, it is necessary to find positions that make it possible to comprehensively analyze the complexity of both the field of practice and the reflection on it. What is needed is "comprehensive knowledge." One of the sources of which may be the concept of social pedagogy, due to its completeness (Radlińska, 1935; Witkowski, 2014) expressed in the integrated paradigm of understanding the field in practice and the activities in it.

Various theoretical positions and approaches lend themselves to different meanings of social work, but what is fundamental is determining whether we understand it as a field of practice (profession, type of practice), or as a separate, self-contained academic discipline (in the substantive rather than institutional sense of it). Answers to this question divide scholars. When considering social work as a discipline, we look for specific reasons, a separate linguistic apparatus, a method of research, and a specific point of view. Furthermore, we question its status and the course of the process of becoming a science of social work. When we think of it as a field of practice, we wonder from what perspectives we can analyze, understand and explore this field, and what approaches can orientate activity in it. We then consider a social employee, their level of professionalism, the methods of work, the consequences, etc.

Obviously, the two perspectives can and even should intersect, but this dichotomous division differentiates the positions and the perception of social work. Since the beginning of the 1990s, Poles have adopted the perspective of combining the disciplines for which social work is an area of study and field of practice, and of searching for common elements. In this way, Poles have been trying to create the conditions for the sharing of concepts, ideologies, values, and goals, in the name of unitas multiplex. Such intentions undoubtedly influenced the present level of development of the social work academic discipline. As a result of discussions held at meetings of the Polish Association of Schools of Social Work, the establishment of several posts of professors of social work was rejected in Poland, a decision which counters those made in some other European countries. In Poland, several (sub) disciplines aspire to analyze the area of social work recognized as a field of practice. One of them is social pedagogy.

This paper will provide an analysis of this outlook and the socio-pedagogical perspective on the field of social work, carried out in relation to the discipline's requirements and development process. This article will tackle this broadly-formulated topic in a context-based way, showing the dilemmas, doubts and conditions of the relationships between social work and social pedagogy.

\section{Social work - multiplicity of meanings: A proposal of a socio-pedagogical interpretation}

In order to get to know the field of social work and activity occurring in it, we can examine it through different perspectives and take different theoretical and methodological approaches that significantly modify its definition and make it a specialized discourse. They include, inter alia, feminist, general, minority, radical, participatory, organization and management, institutional, critical, and other trends. The adoption of a particular theoretical perspective determines the multiplicity of the meanings of social work and differentiates the range of social work in practice. It especially affects the orientation of the activity, which, depending on the specifics of the adopted outlook, is characterized by the following oscillation: 
Marynowicz-Hetka / Social pedagogy and social work: An analysis of their relationship...

15

- $\quad$ From protection, continuance, stabilization, standardization and normalization, distribution of goods and services, management of problems and excesses of power exposed in the relations.

- Through mediating and creating a space of common experience (French: d'expérience partagée $)^{1}$, co-participation, and cooperation.

- To a change in the reforming dimension (transformation, melioration) and in the radical dimension (contestation, systemic change).

This analysis suggests that perceiving social work and attributing meanings to it spans between the field of practice and the disciplinary discourse. It also encourages a question: "What is social work (is to be, should be), the field of practice (action/activity) or the disciplinary discourse, in metatheoretical terms?" The answers often situate it as a field of activity/practice, and also provide for it a description, interpretation, and orientation of activity. One such answer is social pedagogy, a category of action/activity, the analysis of which determines the orientation of professional conduct and builds an integrated paradigm of the activity analysis. ${ }^{2}$

\section{The conditions for creating the discipline in a substantive sense}

Before examining the relationships between the field of social work and social pedagogy as one of the possible meta-theories describing this field of practice, let us examine the conditions for creating the discipline in a substantive sense (Ossowski, 1962).

Many of us, who are engaged in thinking about social work, in educating in this area of practice, in research and activity in this field, put forward this question: "How can social work become a discipline in a substantive sense?" Without going into a detailed discussion of the differences in recognizing when some reflection on the practice already is a discipline, ${ }^{3}$ it should be noted that it is not about "being" a discipline in the formal, institutional sense, which is achieved through establishing a course of studies. Therefore, it is not about decreeing the discipline but about developing it. In this sense, the process of generating an academic discipline on the field of practice and developing theories is typical of the practical disciplines, that is those which - according to Tadeusz Kotarbiński (1961) - are involved in designing, which is expressed through a long phase of "pre-professional" practice. In the case of social work, this phase was formed in Europe as a result of two different teleological interpretations: miser sacra est and miser pudibunda est (Wroczyński, 1964).

The process of generating a discipline related to a field of practice requires an understanding of the elements that define phases and thresholds of becoming a discipline in a substantive sense ${ }^{4}$. In general, the following items are distinguished: the subject, the way of analysis and conceptual apparatus, and the specific point of view, relevant to the discipline. However, it is not only about the specification of individual examples for each of these elements that make up the discipline in a substantive sense, but about its possibly comprehensive/complete vision (Witkowski, 2014).

Similarly, the conceptual apparatus depends on the assumed theoretical approach and should not (as sometimes happens) be only a registry of the events in the language of the practice. In the phase of creating the language of the discipline, this is one of the greatest challenges. The conceptual

1 A term derived from the concept of activity by John Dewey (cf. Dewey, 1968). I refer to it in greater detail, inter alia, in Marynowicz-Hetka (2014, pp. 17-31).

2 I discussed this issue in several texts. For the most comprehensive analysis, see Marynowicz-Hetka (2010).

3 I discussed this issue in the handbook of social pedagogy, Vol. 1 (cf. Marynowicz-Hetka, 2006, 2007, 2009a), Chapter 1.

4 An example of the discipline creation process embracing the influence of practice is the development of social pedagogy and the identification and use of tools for its analysis, including the phases and thresholds of its development (cf. Marynowicz-Hetka, 2006, 2007, 2009a), Chapter 7. 
apparatus on the one hand expresses the applied theoretical and methodological references and is a derivative of the positions and research approaches, and on the other hand, it is altered under the influence of the changing paradigms, as well as the requirements of the language present in the field of practice. It requires a careful analysis of the differences in the vocabulary used in the language of communication and the intelligibility of the activity (Barbier, 2006). In this analysis, what is of particular importance is how the determinants of the intelligibility of an activity are expressed verbally and how it differs from the specificity of the language used by those participating in the field of practice to communicate with other actors. The issue of the language used in the activity constitutes a vast area of analysis that requires interdisciplinary competences (Sierocka, 2003). The map of issues related to the conceptual apparatus of the point of view on action/activity in the field of practice is extensive, and the problem of the semantics of the intelligibility of the activity becomes extremely important for the construction of meaning and the sense of the concepts describing the activity. ${ }^{5}$ Creating the language apparatus is the essence which makes it possible for the scientific discourse to begin to take shape.

\section{Searching for a comprehensive concept for the analysis of the field of social work}

The process of developing the discipline of social work is challenging also because of the complexity of the related field of practice. The complexity of the procedure, which can gradually lead to the emergence of a science (or sciences) concerning social work becomes both a challenge and a requirement. ${ }^{6}$ This requirement of comprehensive thinking and such activities is all the more justified when we do not have aspirations to create the discipline of social work, but we are looking for a meta-theory that will be suitable for us and which in the complete dimension (for instance: social pedagogy) will explain this field of practice and will orient the activity therein. The process of reaching such a concept is also complex.

Primarily, the dilemmas that arise from this position relate to the need to build analytical tools that would allow for the identification of changes taking place towards the complexity of analysis, research, and activity. The preparation of such tools should be preceded by a reflection inter alia on the changes of methodological approaches. The following aspects need to be taken into account:

- The methodological orientations that allow for clarification of that complexity by adopting an interdisciplinary, transversal, integrated perspective.

- Noticing the effects of the methodological shift in research orientations towards ethnographic, participatory research demanding a clear role reversal in the axis of the researcher-the subject.

- Highlighting the ways of understanding, typical for the intersubjectively shared practice: through cooperation or commonalized (shared) experience (experience partagée), requiring in effect the creation of a symbolic space.

- Anticipation of the threats brought by the comprehensive approach, which are most often enumerated in its criticism, manifested in the superficiality of analysis, vagueness and ease of generalization, the lack of analysis tools, etc.

5 For instance, the term habitus, coined by Pierre Bourdieu, introduced to the socio-pedagogical discourse (Marynowicz-Hetka, 2006, 2007, 2009a), which according to Barbier (2006) is the term of intelligibility of activity. It can also be applied as a "mobilizing concept" when its proposed use is to take up an activity (Barbier, 2006, p. 266).

6 It is worth recalling a long discussion on this issue in the European and American circles (cf. StaubBernasconii, 2001; Wagner, 1998; Sibeon, 1996; Sałustowicz, 2003), to name only some of the works in the present discourse. 
Marynowicz-Hetka / Social pedagogy and social work: An analysis of their relationship...

Among the multi-faceted and multi-reference approaches to the analysis of the field of activity and research, perceived as groups of beliefs and analysis tools orienting the exploration of the field, three solutions have been identified: pluridisciplinary, interdisciplinary and transversal. A similarly organized discussion is taking place (Sabirón \& Arraiz, 2014) around the specific logic of forming knowledge (for example that concerning the social processes and phenomena), which departs from the native disciplines and is situated in a cross-disciplinary and therefore complex approach. It becomes "comprehensive knowledge" (Ibid.), determining disciplinary evolution processes (e.g., the science of social work, or the science of education). It runs (Ibid., p. 40) in the following oscillation:

- $\quad$ From the disciplinary approach clearly defining the subject and method of research and giving as a result fragmentary knowledge, applied generally in technological/instrumental solutions.

- Through the pluri-multi-disciplinary approach, which is a meeting point of many disciplines, but each retains its references, and the application of research results evidently raises the level of professionalism.

- The interdisciplinary approach where the redefinition of the object and method of research takes place, which is often a reaction to the discourse position of "the end of science and exhaustion of the object and method of study" (Ibid., p. 40). This is the approach generally useful for the analysis of the field of practice and its optimization.

- To the transdisciplinary approach, which is characterized by the unity of knowledge yielding new meanings and discovering new aspects of reality, e.g., the virtual one (Ibid., pp. 40-41).

This view does not differ much from the viewpoint of Edgar Morin (2007), which is the praise of comprehensive thinking and acting, in contrast to the universal segmentation and fragmentation of these areas, which are dangerous for our social life. The comprehensive approach, both in its scientific and practical dimensions, gives new meaning to the theory and is useful in research and streamlining the activity in the field of practice. It seems that for practical disciplines, it is a recommended path. Social pedagogy is an example of such a comprehensive concept.

However, before this point of view on the field of social work is discussed, it is worth paying attention to the concerns posed by the complexity position. This analysis may be the basis for suggesting questions/assertions for further discussion. First of all, what is the influence of the multiplicity of references and the variety of positions and concepts for the development of social work? Does this multiplicity not generate fragmentation and segmentation in the approaches and in the action/activity in that field? And, consequently, does it not induce the effect of excessive specialty and specialization in education? In other words, does this practice not fit perfectly into the process of institutionalization of social work? Second, can the use of a comprehensive approach to the analysis of the field of social work be a sufficient antidote to its theoretical and conceptual separation? How to reconcile integrated approaches (for instance an integrated paradigm of the analysis of activity), and in particular the model of polyvalent education for activity (by designing) with the expectations of the practice, and especially the limitations of social work to the structures of social assistance, which is a clear casus in Poland. And third, within this line of thinking, the category of action/activity in the field of social work becomes particularly important, together with the analysis of the concept and its development and changes. Social pedagogy has noteworthy proposals in this respect, as will be discussed below.

\section{A comprehensive socio-pedagogical proposal of an analysis of the action/activity in the field of social work}

Against this background of the multiplicity of meanings of social work, the concept of social pedagogy, formulated in the 1930s by Helena Radlińska, has lost none of its freshness. It is expressed by the understanding of the field of activity in areas traditionally linked with social work in terms of 
societal work. This means that such practices of social work, activities "for" individuals, social groups and communities, "together" with them and "through" them, becomes societal work. The activities in the field of social practice understood in this way rather require references to the humanistic paradigm than the technology-related one. The orientation proposed in this approach (societal work) of exerting influence with others and through them allows social work to fulfill the mediation or even contestation function. It proves much less useful in carrying out by the practice of social work only the function of stabilizing the status quo. ${ }^{7}$

The proposed socio-pedagogical perspective allows to a greater extent the fulfillment of this methodical principle of social work, which is defined by the well-known metaphor, give a man a fish and he will eat for a day; teach a man to fish and he will eat for a lifetime, which aptly expresses its educational meaning. This is also associated with a whole set of issues related to the relational model of social work (Marynowicz-Hetka, 2006, 2007, 2009a), which is so important for this perspective and expresses the socio-pedagogical specificity of social work becoming societal work. This specificity is simultaneously the essential link in the relationships between social work and social pedagogy.

The societal dimension of the action/activity in the field of practice of social work - elements of the analytical tool. This part of the analysis includes an attempt to determine the specificity of the societal dimension of social work. In view of the location of action/activity of social work in the social context, its characteristic within the socio-pedagogical dimension is acquiring the attributes of processuality and complexity, as the reality in which this activity (social work) is taken up turns out to be comprehensive and increasingly complex (Marynowicz-Hetka, 2009b).

While analyzing what the societal dimension of the activity in the field of social work is and what it can be, it may be useful to apply such tool of analysis which takes into account the following aspects: the subject, the method of analysis, the conceptual apparatus, the conduct, the specific point of view on the issues of the activity in the field of social practice.

Subject: commonalized experience. The first register of questions, differentiating the positions, includes the following questions: "What are the characteristic features of the situation of performing activity in the field of practice? What are the outer expectations towards it interiorized by the subject? What are the reasons for taking up this activity? and What is the best way to do it?" These are therefore questions concerning the subject of the analysis of the activity. Answering them would require an extensive study and the analysis undertaken in this paper is rather an attempt to provide a contextual answer.

Social work, recognized from the socio-pedagogical perspective, constitutes a certain type of activity in which a special place is occupied by its societal dimension. It is an activity aimed at change and transformation. Therefore, it is a dynamic process, facilitating the engagement of individuals and groups in relationships with themselves, with others and through others. This process is described according to different models, formulated depending on the prevailing theoretical and methodological references.

Adopting the position of John Dewey who stated that the act of construction and reconstruction of experience occurs in interactions (Hałas, 2006; Szacki, 2002, pp. 554-555) and is heading towards commonality, we probably may similarly recognize activity in the field of social practice as a relational (interactive) process. Such reasoning allows for the formulation of the thesis that the specificity of activity in the field of social practice, its essence, sense and meaning will depend on how we perceive social work. If this is the space of commonalized experiences of the subjects of this activity, it also has similar attributes. Consequently, social work acquires the attributes of societal work.

The concept of activity, recognized from the perspective of non-strategic conduct, generates the concept of social activity, understood as an activity of a subject focused on building a symbolic

7 This classification of the functions of social work was proposed by Robert Castel (1998). 
institution (Castoriadis, 1975; Marynowicz-Hetka, 2006, 2007, 2009a) in the milieu, which is the object of the societal dimension of the practice of social work. This practice is aimed at empowering individuals and collectives, which are characterized by four dimensions of the disoeconomicus model (Wagner, 1998): "burden (load), support (base), protection, and subjectification (use)" (Witkowski, 2010, pp. 60-65). They define in a complete way the multiplicity of situations, which an acting subject may come into contact with in the field of social work, and their complexities. They also point to elements that can interact with (and through) one another.

The method of analysis. The second element of the tool is the adopted method of analysis of the phenomenon that is characteristic of a given approach. The issue of the societal dimension of activity in the field of social work cannot be considered in isolation from the social contexts in which this practice is located and in which the research processes are carried out, particularly those relating to its analysis. They are important for the understanding of the societal dimension of activity and the development of the ranges of its senses and meanings. In addition, they matter for its location - not on the outside of these contexts, and not only as an externally-determined attribute, but also within these spaces, as an essential characteristic and the source of credibility of the undertaken activity. Such a perception of the societal dimension of the practice of social work emphasizes the importance of such attributes as relational character, processuality, temporality, contextuality and location. These features define its scope, including the boundaries and possibilities as well as the ways of crossing them. This is also important for the specifics of defining the situation and affects the design of the conduct in which processuality and interactivity are considered special features.

The conceptual apparatus. An essential aspect of the tool is the conceptual apparatus that enables taking care of the overall consistency of the evaluative communication on the activity and explaining its meaning and significance. The core concepts of this apparatus are "social work" and "activity." The first of these is situated within the humanistic and relational paradigm of the model of activity. This makes it possible to proceed to the determination of the societal dimension of this practice. The second, recognized from the perspective of the non-strategic conduct, generates the concept of societal activity understood as an activity of the subject oriented at creating the symbolic institution in the milieu. In both of them, an important function is fulfilled by the concept of "experience," which, subjected to continual reconstruction and reorganization, enriches its content and increases the ability to manage the further process of experiencing (Dewey, 1968). The conceptual apparatus is a derivative of the adopted positions and research approaches. In the concept presented in this article, a particularly important role is played by participatory, interactive and action research approaches.

The construction of the conceptual apparatus affects the vocabulary used in the process of acting and indirectly also the vocabulary applied during the evaluation process. Two types of vocabulary are differentiated: the language of communication and the language of the intelligibility of activity (Barbier, 2006). In particular, it is important to draw attention to the specificity of the language used by the subjects acting in the field of practice, in communication with other participants of the activity. Characteristic features of this type of vocabulary are its strong axiological mark and the fact that its meanings are used simultaneously in several orders: imaginary, affective, and cognitive (Ibid., p. 187). The majority of the statements in this type of communication in the field of practice are assessments of the effects of the activity or inspiring statements to undertake it. In association with the location of the concepts in a kind of a network with others, we note the "inter-meaning relationships of this kind of vocabulary" (Ibid., p. 187).

A specific point of view on the societal dimension of an activity in the field of social work - a relational model of the practice of social work. The key element of the tool of analysis exploring the societal dimension of an activity in the field of social work is the assessment of the selfawareness of the scientific approaches used and their epistemological references. Undoubtedly, the diversity of the assumed perspectives is facilitated by the choice of the theoretical understanding of the activity. For instance, in performing the dichotomous division into a strategic and non-strategic 
activity, ${ }^{8}$ in the former we are "the perpetrators of the deed" and while acting we have the awareness that we influence the natural course of things. We are guided by rational solutions, which in effect are relatively easy to be assessed by a reference to the previously-formulated goals. In the latter (non-strategic activity), in acting, we only change the configuration of a given process, as well as its structure, course, sequence of events, etc. This is of course significant for the occurrence of difficulties in assessing the activity in the field of practice, because it is hard to define clearly the evaluation references and liability of the assessments resulting from the unpredictability of the course of the activity. In these types of activities, evaluation changes status. Often, assessments are expressed probabilistically and heuristically, and they contain many more phrases that are frequently shaped intersubjectively.

The assumed understanding of activity, as a process located in time and space, may be specified closer through its elements: defining the situation, orientation of activity, designing it and implementing it. These are not stages or phases of the activity, but rather components of this spiral process, wherein they can permeate and transform.

The specificity of the point of view on the adopted understanding of the social dimension of activity in the field of social work is expressed in emphasizing the importance of the relational model of such work. Acting with this awareness allows the process to gradually acquire the societal dimension and become societal work oriented at the Other, to find a humanistic dimension of the relationship, based on searching for and revealing individual and collective forces in the milieu and performing activity for this particular milieu, through it, aiming at creating a community, understood as a values-sharing community. It is a systematic and continuous activity, containing the essential features of the process such as anticipation of consequences and rationalization through prior consideration and designing activities focused on transformation and optimization. The most significant features of this activity are determined by its three dimensions: acting for a community, together with it and through it.

\section{Instead of the conclusion - a return to the title: Possible configurations of the relationship between social work and social pedagogy}

Determining the relationships between social pedagogy and social work becomes a problem also because the concept of social work has been "imported" and incorporated from outside of the theoretical system of social pedagogy, where social work was positioned as one of the functions of social pedagogy, thus leaving the area of social activity open also for other disciplines. Social pedagogy not only points to the pedagogical and social issues of social work recognized as societal activity, but primarily explains the mechanisms favoring the act of designing changes and transforming the environments. In this sense, its educational dimension may be outlined, and what is referred to as the educational approach to social work, and social pedagogy itself, may be one of the disciplines that constitute the theoretical bases of the area of social activity, which is defined as social work. At the same time, it still is a good link between the group of educational sciences as well as the culture - and society-related sciences.

Summing up the preliminary terminology findings and referring to the sources of associations of Polish social pedagogy with social work, we are referring to a kind of social pedagogy that raises questions about the societal significance of social work conceived as one of the areas of this field of practice. Thus, referring to the Polish tradition of social work (Radlińska, 1935), it is difficult to talk about the full symbiosis of social pedagogy and social work. However, if the socio-pedagogical point of view of social pedagogy is expressed in its practical dimension, then this function of social

8 Discussed in more detail in Chapter 3 of a handbook of social pedagogy entitled The category of social activity - the sense and importance (cf. Marynowicz-Hetka, 2006, 2007, 2009a). The inspiration for this typology was the proposal of Jürgen Tillmann (2005). 
Marynowicz-Hetka / Social pedagogy and social work: An analysis of their relationship...

pedagogy in relation to social work is particularly accented. Furthermore, in the adopted analysis, we only emphasize the recognition of social work as an area of practice and culture of the profession creating it, but we do not analyze the positions related to the process of academization and disciplinarization of social work observed in many countries (Sałustowicz, 2003).

The importance of social pedagogy for orienting the activity of the subject in the field of practice is that it forms the basis for constructing:

- Tools to analyze and explain the situation and their evaluation and interpretation (for example: a qualitative measurement, the overall index of the environment, and a tool to assess the threshold of development risk).

- Models and patterns as well as valorizing perceptions/representations (axiological), which may constitute grounds/reasons for engaging in an activity from the socio-pedagogical perspective.

- Anticipating and optimizing imaginings/representations necessary to create projects and proposals for transforming the environment, facilitating the construction of methodological reasons that form the answers to the questions "how to act?" and "why act in such a way?" Among these are affecting by enhancing the forces of the milieu, which in turn can be done by the training/formation (French: formation, German: Bulding) of the acting subjects; affecting through forecasting and anticipating the events; exerting influence by creating a community - creating the symbolic institution. ${ }^{9}$

Reflecting on the possible associations of social pedagogy and social work, as well as on what a sociopedagogical orientation can contribute to social work understood as a field of action/activity, it is worth noting that this specificity of social pedagogy and its usefulness for social work is expressed in four characteristics that briefly define its point of view. These are globality, dynamics, compensation and valuation.

The quality of relationships between social pedagogy and social work will depend among other things on:

The level of development of reflection in the field of social work as the field of operation, the field of professional activity.

- The level of institutionalization of social work and social pedagogy, expressing itself both in the creation of formal institutions (research centers, education centers, schools of social work, research fields), and in the forms of institutionalization occurring within the existing structures. An important distinguishing feature is the process of academization of education for the field of social work, expressed in the establishment of a course of study at three levels of higher education.

- Isolating or inclusive tendencies within social work and social pedagogy. The discussion on this topic was begun by Antonin Wagner, who asked, "are we representing a homogeneous or heterogeneous paradigm?" (Wagner, 1998).

- Views as to what social work is: a field of activity, in other words, the practice of social pedagogy (Urbaniak-Zając, 2003, p. 32), or, as defined by Wagner (1998), the societal work, or even a separate discipline, which has its own subject and research methods (Sałustowicz, 2003).

While observing the practice of social work or the expectations imposed on it by society, and while analyzing the results of the reflection on it and thinking about it, one gets the impression of an

In the concept of social pedagogy presented in this paper, an important category is the symbolic institution discussed in chapter 3 of the handbook of social pedagogy (Marynowicz-Hetka, 2006, 2007, 2009a). It is a development of the concept of the invisible environment formulated by Radlińska (1935) and approximated to modern readers by Lech Witkowski (2014). 
explicit dissonance between designing the reality and the reality itself. We may simply say that the practice of social work "does not match" the increasingly common paradigms situated within the understanding of others, in their participation, which is generally referred to as the non-strategic activity. Specifically, a gap is created when its societal dimension, located inherently in the complex process of activity in the field of social work, is overlooked. Consequently, operations in the field of social work are often limited to individual acts, isolating individual components of the complex process of activity from the whole.

The idea of comprehensive thinking is very much present in social pedagogy (Radlińska, 1935), which is seen as a "complete" concept (Witkowski, 2014). In the center of its interests, there are diverse fields of practice. The complexity of observed social phenomena requires a deeper reflection on the activity of subjects located therein. Social pedagogy is a certain mainstream of transversal thinking that situates itself "at the crossroads of the human, cultural, social and educational sciences." It refers to such currents of thought as progressivism and pragmatism. The problem of cooperation is one of the most important in its discourse.

The complexity of social phenomena observed in various fields requires a deep reflection on the activities of the engaged actors. These activities can take many forms. One of them is societal work, which refers to concepts comprising epistemological elements related to "how to work together." These include such categories as processuality, breaking, the relational character of the approaches, which can be summed up by the expression, "I give-I take" (Radlińska, 1935; Dewey, 1968) and the concept of the invisible environment (Radlińska, 1935), the symbolic institution (Castoriadis, 1975), or a double-bind (Bateson, 1979), to enumerate only a few of them. These are all contained in the culture of practice/activity (Barbier, 2011).

The culture of the practice of social pedagogues is saturated with the idea of co-operation, which means doing "with", "for", "together" and also "through/owing to others." A particular advantage of this cooperation are the Others, that is individuals or collectives that we are looking for in the milieu, going beyond/growing above others, due to their capabilities, possibilities and availability. These are individuals capable of transforming the space into a community in which the primary merit is the sharing of values, emotions, affections, and thoughts.

This analysis leads us to the concept of commonality of experience and co-design of space developed by Dewey (1968). Its specific feature is the dynamics of the reconstruction of experience shared with others. The concept of commonalized experience enriches an important category of social pedagogy, namely the concept of the invisible environmental and the symbolic institution, emphasizing at the same time the multi-dimensionality of space. Thus, social pedagogy, understood in this holistic/comprehensive way, may provide for social work and its practice an extensive proposal of meta-theoretical overview of the field and its changes.

\section{References}

Barbier, J.-M. ( 2011). Vocabulaire d'analyse des activités. Paris: PUF.

Barbier, J.-M. (2006). Działanie w kształceniu i pracy socjalnej. Analiza podejść (Activity in education and social work. Analysis of approaches). Katowice: Wyd. Naukowe "Śląsk".

Bateson, G. (1979). La nature et la pensée. Paris: Edition du Seuil.

Castel, R. (1998). Du travail social à la gestion social du non travail. Esprit, 241, 28-47.

Castoriadis, C. (1975). L'institution imaginaire de la societé. Paris. Edition du Seuil.

Dewey, J. (1968). Éxpérience et education. Paris: Librairie Armand Colin.

Hałas, E. (2006). Interakcjonizm symboliczny. Społeczny kontekst znaczeń. Wydanie nowe [Symbolic interactionism. The social context of meanning. New and changed edition]. Warszawa: Wydawnictwo Naukowe PWN. 
Marynowicz-Hetka / Social pedagogy and social work: An analysis of their relationship...

Kotarbiński, T. (1961). Elementy teorii poznania, logiki formalnej i metodologii nauk [Elements of the theory of cognition, formal logic and methodology of science]. Wrocław: Ossolineum.

Marynowicz-Hetka, E. (2006, 2007, 2009a). Pedagogika społeczna. Podręcznik akademicki. Wykład [Social pedagogy. Academic handbook. Lecture]. Warszawa: Wydawnictwo Naukowe PWN.

Marynowicz-Hetka, E. (2009b). Vers la pensée complexe dans la formation pour l'action au champs de la pratique. In O. Chytil, G. J. Friesenhahn, F. W. Seibel, J. Windheuser, \& A. Verlang (Eds.), Professions sociales pour une Europe sociale. Rétrospective - Aperçu - Perspective [Sociálni Profese pro Sociální Europu. Zhodnoceni - Nahled - Perspectiva/Conference: Konferenzbericht/Conference Proceedings/Actes de Conférence/Sborník z konference] (pp. 100-110). Boskovice: University of Ostrava.

Marynowicz-Hetka, E. (2014). Orientowanie działania - rama konceptualna pojmowania kultury praktyki [Orienting the activity - conceptual framework of understanding the culture of practice]. In E. Marynowicz-Hetka, L. Filion, \& D. Wolska-Prylińska (Eds.), Kultura praktyki przedstawicieli profesji społecznych - podejścia mediacyjne $w$ działaniu społecznym (pp. 1731). Łódź: Wyd. Uniwersytetu Łódzkiego.

Marynowicz-Hetka, E. (2010). W nawiązaniu do propozycji zintegrowanego paradygmatu pedagogiki społecznej - ramy dyskusji [In connection with the proposed integrated paradigm of social pedagogy - a framework for discussion]. In J. Piekarski, T. Pilch, W. Theiss, \& D. Urbaniak-Zając, Edukacja społeczna wobec problemów współczesnego człowieka i społeczeństwa (pp. 73-90). Łódź: Wyd. UŁ, WNoW UŁ.

Morin, E. (2007). Vers l'abime? Paris: L' Herne.

Ossowski, S. (1962). O osobliwościach nauk społecznych [On the peculiarities of social sciences]. Warszawa: Wydawnictwo Naukowe PWN.

Radlińska, H. (1935). Stosunek wychowawcy do środowiska społecznego. Szkice z pedagogiki społecznej [The attitude of an educator to the milieu societal. Sketches of social pedagogy]. Warszawa: Nasza Księgarnia.

Sabirón, F., \& Arriaz, A. (2014). Complexité et recherche en éducation: La construction complexe des savoirs scientifiques en éducation. In R. Marmoz (Ed.), La recherche en éducation - Pluralité et complexité (pp. 31-42). Paris: L'Harmattan.

Sałustowicz, P. (2003). Praca socjalna. Między dyscyplina a profesjq [Social work. Between the discipline and the profession]. Katowice: Wydawnictwo Naukowe "Śląsk".

Sibeon, R. (1996). Konstruowanie współczesnej socjologii pracy socjalne [Construction of modern sociology of social work]. In M. Davies, Socjologia pracy socjalnej (pp. 31-85). Warszawa: Interart.

Sierocka, B. (2003). Jedność performatywno - propozycjonalna a perspektywa antropologiczna [The performative-propositional unity and the anthropological perspective]. In B. Sierocka (Ed.), Via Communicandi. Przełom komunikacyjny a filozoficzna idea konsensusu (pp.167-182). Wrocław: Wydawnictwo ATUT.

Staub-Bernasconi, S. (2001). Przedmiot pracy socjalnej - rozwój podejść teoretycznych w ujęciu porównawczym [The subject of social work - the development of theoretical approaches in comparative terms]. In E. Marynowicz-Hetka, A. Wagner, \& J. Piekarski (Eds.), Profesje społeczne w Europie. Z problemów kształcenia i działania (pp. 40-62). Katowice: Wydawnictwo Naukowe „Śląsk".

Szacki, S. (2002). Historia myśli socjologicznej [History of sociological thought]. Warszawa: Wydawnictwo Naukowe PWN. 
Marynowicz-Hetka / Social pedagogy and social work: An analysis of their relationship...

Tillmann, J. (2005). Teorie socjalizacji. Społeczność. Instytucja. Upodmiotowienie [Theories of socialization. Community. Institution. Empowerment]. Warszawa: Wydawnictwo Naukowe PWN.

Urbaniak-Zając, D. (2003). Pedagogika społeczna w Niemczech. Stanowiska teoretyczne i problemy praktyki [Social pedagogy in Germany. Theoretical viewpoints and the problems of practice]. Łódź: Wydawnictwo Ut.

Wagner, A. (1998). Debata o pracy socjalnej/pedagogice społecznej- reprezentujemy homogeniczny czy heterogeniczny paradygmat naukowy [A debate about social work/social pedagogy - do we represent a homogeneous or a heterogeneous scientific paradigm]. In E. Cyrańska, E. Marynowicz-Hetka, \& J. Piekarski (Eds.), Pedagogika społeczna jako dyscyplina akademicka. Stan i perspektywy (pp. 455-462). Łódź: Wydawnictwo Ut.

Witkowski, L. (2010). Praca socjalna i profesjonalizm pedagogiczny. O zarzq̨dzaniu humanistycznym: między filozofiq edukacji i pedagogikq społecznq [Social work and pedagogical professionalism. On the management of the humanities: between philosophy of education and social pedagogy]. Łódź: WSEZiNS.

Witkowski, L. (2014). Niewidzialne środowisko. Pedagogika kompletna Heleny Radlińskiej jako krytyczna ekologia umysłu i idei i wychowania. O miejscu pedagogiki w przełomie dwoistości w humanistyce [The invisible environment. Complete pedagogy of Helena Radlińska as critical ecology of mind and ideas and education. On the place of pedagogy at the turn of the duality in the humanities]. Kraków: Oficyna Wydawnicza „Impuls”.

Wroczyński, R. (1964). Od filantropii do pedagogiki opiekuńczej [From philanthropy to pedagogy of care]. Studia Pedagogiczne, 12, 8-24. Wrocław-Warszawa-Kraków: Ossolineum. 